\title{
Is there a "right not to be born"? Reproductive decision making, options and the right to information
}

\section{J Savulescu}

A n Indian Court recently awarded 50,000 rupees damages to a couple who gave birth to their fourth daughter. The couple were mistakenly told they were carrying a male fetus. The doctor mistook a section of the umbilical cord for a penis. The husband said: "We are already struggling to raise three children. This was a big sacrifice for us to have a fourth child. We would have had an abortion if we had known it was a girl". The cost of damages amounted to the dowry they would have to pay at the time of their daughter's marriage.

This is a fictional case. But the cases of Nicholas Perruche and Lionel ${ }^{1}$ are not fictional. According to reports, damages were paid to these children on the basis of what the media has described as a "right not to be born". Is there a "right not to be born?" Was it right to compensate Nicholas Perruche for being born with congenital rubella and Lionel for being born with Down's syndrome?

\section{HARM TO THE CHILD}

What constitutes a right is a complex question. On one interpretation, rights protect interests. This implies that a right not to be born would exist if a child had an interest in not being born. Is it ever in a child's interests not to have been born? If it were, this might imply the child is better off dead than alive, as the Collective against Handiphobia claim. Is it better to be dead than have Down's syndrome?

Some people do believe that Down's syndrome constitutes a life not worth living. ${ }^{2}$ But this view seems false. Children with Down's syndrome can and often do lead happy and worthwhile lives. After all, we do not suggest that other (non-human) animals have a right not to be born or a life not worth living because their intelligence does not measure up to the human average.

There may be a few conditions which afflict humans which are so terrible that they are comparable to death. People who are permanently unconscious in a persistent vegetative state have lifeprolonging medical treatment withdrawn on the basis that continued treatment is not in their interests. Permanent unconsciousness is like death. If one had a life of constant pain, limitation of movement and sensation, and severe impairment of the ability to interact with other people the world might be worse than death. But mild to moderate intellectual disability is not such a condition.

What of the claim by the lawyer, Portejoie, that the harm was not being born but the suffering associated with disability. Is this a basis for compensation? One could deny that people with intellectual disability suffer. But let us grant for argument's sake that they do "suffer" in the sense of being worse off than some ordinary person. Are they harmed by such suffering? To claim that they are harmed is to claim that they are worse off than they would otherwise have been if they did not have their intellectual disability. To be harmed by an act (in the case of Lionel, the failure to pick up a sign of Down's syndrome) is to be made worse off than one would otherwise have been if that act had not been performed. Lionel was not harmed by the failure to pick up his Down's syndrome (if anything, he was benefited from not being aborted). It is absurd to pay damages to Lionel, whose only chance of a worthwhile life was as a child with Down's syndrome.

We all suffer during our lives. Perhaps Portejoie is making the very radical claim that we should all be compensated because we suffer, at least in those cases in which our parents chose not abort us. On this radical egalitarian programme, every person who develops an illness or sustains an injury should receive compensation for it.

This, however, confuses compensation with social services or social support. There is no doubt that there are inadequate social supports for children with disabilities. It is not, however, appropriate to arbitrarily choose medical compensation to remedy this. Doctors should compensate children when their actions or omissions harm the children. There is no basis, however, for compensating a child for a disability which is constitutive of that child's existence (unless the disability is so bad that it renders life not worth living). In cases A, B, E, and F ( see Six hypothetical cases below) the child born is worse off than other normal children. However, the child is not harmed by being born with that condition if its life with that disability is worth living. The alternative for these children is not a normal life, but non-existence.

Cases $\mathrm{C}$ and $\mathrm{D}$ are different. In these cases, the child could have been born without disability. These children have been harmed by their doctor's act or omission. They are candidates for medical compensation.

\section{HARM TO THE COUPLE}

Prior to the Perruche judgment, only couples affected by the birth of disabled child were compensated. Indeed, Nicholas Perruche's parents had already been

\section{Six hypothetical cases}

Case A. A fetus is diagnosed with a large diaphragmatic hernia, or hole in the diaphragm. The prenatal ultrasound findings suggest that without intrauterine surgery the baby is likely to die after bith from pulmonary hypoplasia. $\operatorname{Dr}$ A performs fetal surgery. The baby lives, but has chronic respiratory problems. The child can only walk short distances and can never play sport.

Case B. An 18 week ultrasound scan shows that a fetus has a small exomphalos, which itself could easily be surgically repaired. However, there is an association with, among other things, Trisomy 18. Dr B does not inform the pregnant woman of this association or of the availability of further prenatal tests. The baby is born with Trisomy 18, has severe intellectual disability and cardiac abnormalities. She dies in the first year of life.

Case C. Dr C attempts an amniocentesis and inserts the needle into the fetus's brain, causing a haemorrhage. The child is born with significant brain damage.

Case D. Dr D sees Mrs Smith for a prenatal check up. He fails to inquire about her diet or to advise her of the relationship between folate supplementation and lower incidence of spina bifida. She becomes pregnant and has a child with spina bifida.

Case E. Dr E performs an ultrasound scan and fails to detect a defect in the spine. The baby is born with spina bifida.

Case F. Dr F diagnoses a bladder neck obstruction in a male fetus which, if not corrected, will cause kidney failure. No other abnormalities are seen on the ultrasound. No other abnormalities are known to be associated with this. The doctor bypasses the obstruction with a vesico-amniotic catheter at 20 weeks. The baby is born but is unable to swallow and must have permanent gastrostomy feeding. 
compensated prior to the Perruche judgment which compensated him. To have a child whom one does not want is a great harm. The clearest case of harm to parents is when one or both parents reluctantly sacrifice their life to nurse their severely disabled child. Many parents of disabled children find caring for their disabled child a positive and rewarding experience. But others do not, and if their situation is the result of medical incompetence, they are deserving of compensation for it.

The same principle applies to the birth of any child, abled or disabled. Imagine a doctor wrongly and incompetently interprets a pregnancy test in a single woman. By the time she realises she is pregnant, no one will offer a termination of pregnancy. This woman desperately does not want a child but feels she cannot have it adopted. She gives up a promising career for a less demanding one to care for her child. She gives up her hopes of being a professional actor. She should be compensated for her losses.

Some disability activitists draw attention to the inconsistency in attitudes to testing for Down's syndrome and sex selection. Most people accepted testing and termination of pregnancy for Down's syndrome but reject sex selection for non-medical reasons. These activists claim that this implies that fetuses with Down's syndrome are "devalued" and this represents unfair discrimination. I agree. ${ }^{3}$ If we accept:

- it is a harm to a couple to have a child with Down's syndrome (when there existed a reliable test for that condition and they would have had a termination of pregnancy if the test had been competently performed)

then we should also accept,

- it is a harm to a couple to have a child of an undesired sex (when there existed a reliable test for that condition and they would have had a termination of pregnancy if the test had been competently performed).

Compensation to the Indian couple described in the hypothetical example is as deserved as compensation to the parents of Nicholas Perruche and Lionel. When we only allow testing and termination of pregnancy for Down's syndrome and other disabling conditinons, we do engage in unjustifiable eugenics and discrimination. ${ }^{3}$ The solution is not to prevent testing but to widen testing to include all relevant information about a pregnancy.

\section{NEGLIGENCE}

It is not enough for a doctor to have harmed a patient for compensation to be due. For compensation to be due, the doctor must have acted unreasonably. Sometimes doctors do the best job they can, and children or couples are harmed. As the president of the College of Echocardiography said, medicine is never $100 \%$. Even if the couple treated by Dr F would have had a termination of pregnancy if they had known about their child's swallowing abnormality, Dr F should not compensate them for this if there was no reason for him to believe such an abnormality existed. Doctors should not be held responsible for not telling what they did not reasonably know. Dr $\mathrm{F}$ is different from doctor B-Dr B should have known and should have described this association between exomphalos and Trisomy 18. In F's case, the association between was not so clear. In the case of $\mathrm{A}$, the parents should be compensated for having to care for a child with chronic respiratory difficulties, if this possibility was known by their doctor but not raised at the time of consideration of fetal surgery. If, however, it was broached, the parents have no claim against the doctor.

Given the widespread knowledge of the relationship between folate and spina bifida, Dr D's failure to inquire and advise in this matter was unreasonable. Was doctor E's failure to detect the spina bifida unreasonable? This depends on the nature of the defect and whether it is reasonable to expect an ultrasonologist to detect it. If it were large and the doctor was unskilled and performed a perfunctory examination, it would be unreasonable. If it was very small, and there were no other signs, it may be reasonable to have missed it. Most cases of spina bifida should be picked up. Dr C is probably negligent - with proper ultrasound guidance, there should be no reason to insert the needle into the baby's brain.

\section{LESSONS FROM PERRUCHE AND THE ACT OF TELLING}

These French cases are not primarily about some "right not to be born". They are about the rights of couples and other people engaging in procreative activities to be given a reasonable range of options and good quality information relevant to those options. There were serious, avoidable deficiencies in what the parents of Nicholas Perruche were told.

The moral principles which lie behind the Perruche decision have very wide implications. Medicine is turning up more and more information about minor states or non-disease states. For example, compound heterozygotes for cystic fibrosis (who have two mutations but one mutation is a mild form) are likely to be free of significant symptoms. Or female carriers of the haemophilia gene may only have very mild bleeding and a $50 \%$ chance that their sons will have haemophilia. Some couples want to know if their child is a compound heterozygote for cystic fibrosis or if their female fetus is a carrier or if their child is a healthy carrier of a gene for mental retardation which may be expressed in the next generation. If tests for these abnormalites can be offered within a fair allocation of limited health resources, they should be provided. And when provided they should be offered to a reasonable standard with information about the options available. Revealing sex from an ultrasound scan which is performed for other medical reasons costs virtually nothing. The only cost is the cost of a termination of pregnancy if that occurs, and that is something people are entitled to (according to certain legal criteria), whatever their personal reasons.

\section{HOW MUCH SHOULD COUPLES BE TOLD?}

Couples should be told information (consistent with the fair allocation of limited health resources):

- which is relevant to the wellbeing of their child (Cases A-F)

- which is relevant to their own wellbeing (Cases A-F, the hypothetical case of sex selection).

In general, people are the best judge of what is in their overall interests. It is for this reason that a recent Australian judgment in negligence is so important. ${ }^{4}$ Australian courts have rejected the Bolam standard of disclosure. According to the Bolam standard, doctors should disclose those facts about medical procedures which a reasonable body of similar medical practitioners would disclose. Rather, Australian courts require a much more stringent degree of disclosure: a subjective standard where doctors are expected to disclose those facts which each individual patient would find relevant to her decision making. A similar principle should apply to decisions related reproduction.

I don't know if there is a right not to be born. But there is undoubtedly a right to information and a right to make choices about how many children we have, and when we have them and what kind of children we have. The French cases of Perruche and Lionel draw attention to the importance of informed procreative autonomy or reproductive freedom. ${ }^{5-9}$

J Med Ethics 2002;28:65-67

\section{Author's affiliations}

Correspondence to: Julian Savulescu; savulesj@cryptic.rch.unimelb.edu.au 


\section{REFERENCES}

1 Spriggs $M$, Savulescu J. Current controversy: The Perruche judgment and the right not to be born. Journal of medical ethics2002;28:63-4.

2 Molenaar JC. The legal investigation of a decision not to operate on an infant with Down's syndrome and duodenal atresia. Bioethics 1992:6:35-40.

3 Savulescu J. Is current practice around late termination of pregnancy eugenic and discriminatory? Maternal interests and abortion. Journal of Medical Ethics 2001;27: 165-71.

4 Rogers v Whitaker (1992) 175 CLR 479

5 Dworkin R. Life's dominion: an argument about abortion and euthanasia. London: Harper Collins, 1993.

6 Harris, J. Goodbye Dolly? The ethics of human cloning. Journal of Medical Ethics 1997;23:353-60.
7 Harris J. Rights and reproductive choice. In: Harris J, Holm S, eds. The future of reproduction. Oxford: Clarendon Press, 1998

8 Robertson JA. Children of choice: freedom and the new reproductive technologies. Princeton: Princeton University Press, 1994

9 Strong C. Ethics in reproductive and perinatal medicine. New Haven: Yale University Press, 1997.

\section{Cadaveric organ donation: call for papers}

The journal is planning to publish a series of papers on cadaveric organ donation in the December 2002 issue.

Anyone interested in writing on this subject should send a short outline of their proposed paper to the Editor, Julian Savulescu at: savulesj@cryptic.rch.unimelb.edu.au Instructions to authors are available online at www.jmedethics.com/misc/ifora.shtml 